\title{
Explanatory notes
}

Unless otherwise indicated, "manufacturing" includes the industry groups listed under section C (Revision 4) of the International Standard Industrial Classification of All Economic Activities (ISIC) [Statistical Papers, Series M, No.4/Rev.4 (United Nations publication, Sales No. E.08.XVII.25)] or category D (Revision 3) of ISIC [Statistical Papers, Series M, No.4/Rev.3 (United Nations publication, Sales No. E.90.XVII.II)].

ISIC code numbers are accompanied by a descriptive title (for example in the case of Revision 4 of ISIC, ISIC 2023: "Manufacture of soap and detergents, cleaning and polishing preparations, perfumes and toilet preparations"). For considerations of space, however, the description is sometimes shortened (that is, ISIC 2023 may be described simply as "Soap, cleaning and cosmetic preparations"). For Revision 3 and 4 of ISIC, all 2- , 3- and 4-digit codes and their corresponding descriptive titles are listed in appendix II to the introduction.

In the presentation of several statistical tables in part I, individual countries and areas are presented by economies. They are listed alphabetically whenever appropriate, within two successive categories: "industrialized economies" and "developing and emerging industrial economies". Designation of economies as "industrialized" or "developing and emerging industrial" is based on adjusted manufacturing value added (MVA) per capita, which is a statistical measure derived from the share of MVA in gross domestic product (GDP) at 2015 current prices and GDP per capita in 2015 at the purchasing power parity (PPP) rates. This measure reflects an approximate value of MVA per capita at PPP rates. An economy is considered to be "industrialized" if its adjusted MVA per capita is higher than 2,500 international dollars or its GDP per capita is higher than 20,000 international dollars at PPP rates. Similarly, an "emerging industrial economy" corresponds to an economy with an adjusted MVA per capita ranging between 1,000 and 2,500 international dollars or an economy whose share of world MVA is higher than 0.5 per cent. All remaining economies fall in the category of "other developing economies". The list of least developed countries (LDCs) is based on decisions of the United Nations General Assembly. Users are advised to note that MVA per capita presented in the Yearbook is in United States dollars, not in PPP.

Data are also presented by income groups: high income, upper middle income, lower middle income and low income. These four country groups correspond to the World Bank's definition for each income category. The list of economies by all country groups used in the Yearbook is provided in appendix I to the introduction. Owing to a lack of data, some economies could not be included in their respective groups in some tables.

In the present publication, unless otherwise stated, data for China do not include data for Hong Kong SAR, for Macao SAR or for Taiwan Province of China, which are presented separately under China (Hong Kong SAR), China (Macao SAR) and China (Taiwan Province).

The United Kingdom left the European Union on 31 January 2020. All aggregates for the European Union presented in part I of this publication include its 27 member countries only (see appendix I). Users are therefore advised to bear this in mind when comparing aggregates with those published in earlier editions of the Yearbook.

Data for Ireland indicate a substantial increase in manufacturing output and value added from 2015 onwards, as presented in part I and II of this Yearbook. This increase is primarily attributable to the relocation of a limited number of multinational companies to Ireland, in particular their intellectual property rights. Users are advised to exercise caution 
when interpreting these data and to be aware of limited data availability by ISIC due to statistical disclosure control measures of the Central Statistics Office of Ireland.

In part I, references to dollars $(\$)$ are to United States dollars. National currencies have been converted to dollar equivalents by using period average exchange rates as published in International Financial Statistics (International Monetary Fund publication) and other sources.

Data converted to dollars by using current exchange rates are liable to be strongly influenced by fluctuations in exchange rates. Annual variations of data converted in that manner may not reflect movements in the national data.

Unless otherwise noted, average annual growth rates are calculated from the data available for each year of a given period (for example, 2010-2020), using a semi-log regression over time. Growth rates are expressed in percentages.

Periods set off by a hyphen (for instance, 2010-2020) include the beginning and end years.

Apparent arithmetic discrepancies, such as percentages that do not add up to precise totals, result from the rounding of basic data or figures known to different degrees of precision.

Three dots (...) indicate that data are not available or are not separately reported.

A dash ( - ) indicates that an amount is nil or negligible.

The letter " $x$ " designates the item applicable to an economy when several options exist.

To avoid ambiguity, the letters "l", "o" and "O" are not used to designate footnotes.

The following abbreviations and acronyms are used:

$\begin{array}{ll}\text { ASEAN } & \text { Association of Southeast Asian Nations } \\ \text { CACM } & \text { Central American Common Market } \\ \text { CARICOM } & \text { Caribbean Community } \\ \text { CEMAC } & \text { Central African Economic and Monetary Community } \\ \text { CIS } & \text { Commonwealth of Independent States } \\ \text { ECOWAS } & \text { Economic Community of West African States } \\ \text { EIE } & \text { emerging industrial economy } \\ \text { EU } & \text { European Union } \\ \text { Eurostat } & \text { Statistical office of the European Union } \\ \text { GCC } & \text { Cooperation Council for the Arab States of the Gulf } \\ \text { GDP } & \text { gross domestic product } \\ \text { IIP } & \text { index of industrial production } \\ \text { ISIC } & \text { International Standard Industrial Classification of All Economic Activities } \\ \text { LAIA } & \text { Latin American Integration Association } \\ \text { LDC } & \text { least developed country } \\ \text { MERCOSUR } & \text { Common Market of the South/ Mercado Común del Sur } \\ \text { MVA } & \text { manufacturing value added } \\ \text { NACE } & \text { statistical classification of economic activities in the European } \\ & \text { Community/ Nomenclature statistique des activités économiques dans } \\ & \text { la Communauté européenne } \\ \text { n.e.c. } & \text { not elsewhere classified } \\ \text { n.e.s. } & \text { not elsewhere specified } \\ \text { NSO } & \text { national statistical office }\end{array}$


OECD Organisation for Economic Co-operation and Development

PPP

SAARC

SADC

UNIDO

UNSD

VAT purchasing power parity

South Asian Association for Regional Cooperation

Southern African Development Community

United Nations Industrial Development Organization

United Nations Statistics Division

value added tax

WAEMU/UEMOA West African Economic and Monetary Union 
UNIDO - 9781800886506 